\title{
Correction to: Drug-related factors affecting medication adherence among Egyptian asthma patients
}

\author{
Abdellah H. K. Ali, Esraa Ameen, Kamal Atta and Khaled Fawzy Alkhayat
}

\section{Correction to: Egypt J Bronchol (2020) 14:35 \\ https://doi.org/10.1186/s43168-020-00035-w}

After publication of the original article [1], the author identified that Table 2 was a duplicate of Table 1 . The duplicate has been deleted and the tables renumbered.

The original article has been corrected.

Published online: 10 November 2020

\section{Reference}

1. Ali AHK et al (2020) Drug-related factors affecting medication adherence

among Egyptian asthma patients. Egypt J Bronchol 14:35 https://doi.org/10.

1186/s43168-020-00035-w

* Correspondence: abdellahdiab@outlook.com

Department of Respiratory Medicine, Sohag Faculty of Medicine, Sohag

University, Sohag 82524, Egypt

(อ) The Author(s). 2020 Open Access This article is licensed under a Creative Commons Attribution 4.0 International License, which permits use, sharing, adaptation, distribution and reproduction in any medium or format, as long as you give appropriate credit to the original author(s) and the source, provide a link to the Creative Commons licence, and indicate if changes were made. The images or other third party material in this article are included in the article's Creative Commons licence, unless indicated otherwise in a credit line to the material. If material is not included in the article's Creative Commons licence and your intended use is not permitted by statutory regulation or exceeds the permitted use, you will need to obtain permission directly from the copyright holder. To view a copy of this licence, visit http://creativecommons.org/licenses/by/4.0/. 